\title{
Succession Pool Establishment in General Education System of Russia: Problems and Prospects
}

\author{
Eugenia Gerasimova ${ }^{1}$ \\ Irina Karpacheva² \\ Irina Kolosova ${ }^{1}$ \\ Dmitry Polyakov² \\ Nina Fedina ${ }^{3}$ \\ Tatiana Shchuchka ${ }^{4}$ \\ 1 Institute of Psychology and Pedagogy, Department of Psychophysiology and Pedagogical Psychology, \\ Yelets State Bunin University, Yelets, Russian Federation \\ ${ }^{2}$ Institute of Psychology and Pedagogy, Department of Psychology and Pedagogy, \\ Yelets State Bunin University, Yelets, Russian Federation \\ 3 Institute of Psychology and Pedagogy, Department of Pre-school and Special Education, \\ Yelets State Bunin University, Yelets, Russian Federation \\ ${ }^{4}$ Institute of Mathematics, Natural Science and Engineering, Department of Mathematical Modelling and Computer Technologies, \\ Yelets State Bunin University, Yelets, Russian Federation \\ Correspondence: Eugenia Gerasimova, Yelets State Bunin University, \\ 28 Kommunarov St., Yelets, 399770, Lipetsk Region, Russian Federation \\ E-mail: rector@elsu.ru
}

Doi:10.5901/mjss.2015.v6n5s4p372

\section{Abstract}

This article examines special characteristics of the practice of succession pool establishment in the current general education system of the Russian Federation. Documents published on official websites of local and regional executive educational authorities, as well as methodical and informational materials characterizing establishment and development of succession pool in the general education system were analyzed. All subjects of the Russian Federation were covered by analysis. The period of 2010-2015 was studied. The authors of the article determined that the practice of succession pool establishment in the general education system is associated only with filling in vacant managerial positions. The researchers discuss deficiencies of that approach regarding improvement of human resources supply, because the main problems of the system are lack of staff in general, lack of young specialists, and aging of educational staff. As a tool to solve the problems mentioned above, the authors propose to use an expanded version of the practice of succession pool generation, which involves not only an operating pool, but also a strategic pool and a pool of young specialists.

Keywords: human resources management, succession pool, operating pool, strategic pool, young specialists, general education system of the Russian Federation, staff turnover, professional mobility, recruiting, headhunting, job bank

\section{Introduction}

\subsection{Introduction of the Problem}

Quality and potential of human resources are essential for viability and effectiveness of any organization. In academic and practical spheres of human activity, that area is defined as human resources management, or HR-management.

The theory of human resources management was established and developed by such researchers as F. Taylor, E. Mayo, A. Maslow, K. Lewin, M. Weber, F. Herzberg, and D. McClelland. Most works on theory of HR management study commercial structures.

The issue of improving performance of public organizations, in particular-educational ones, is relatively new for Russian researchers. The key reasons proving its relevance are the following: increasing internal and external 
competitiveness in educational system; change of the social order towards improving the quality of provided educational services; variability and flexibility of development and upbringing of a personality in multicultural environment, etc.

Novelty and relevance of applying the ideas of HR management in general education is supported at the legislation level as well. In the strategic plan of innovative development of Russia (Decree of the Government of the Russian Federation from December 8, 2011 "About the Strategy for innovative development of the RF till 2020"), the need to form a succession pool is defined as one of the top-priority tasks.

An attempt of legislators to apply the practice of succession pool establishment in the general education system is explained by their wish to speed up innovative development of Russia, which includes improvement of quality of general education. That Decree of the Government of the RF contains goals for development of general education, professional education, and social and economic sector in the context of solving the issue of preparation of educational and managerial human resources which would meet the requirements of innovative development stated in the social order. Most of those goals are already achieved or being achieved now. In particular, they are reflected in modernization of professional education and general education at the level of development and introduction of new educational standards: federal standards for higher education (FGOS BO 3+) and federal standards for general education (FGOS OO of the second generation). It is also worth to mention "Educator" professional standard (educational activity in pre-school, elementary general, basic general, and secondary general education) (nursery school teacher, school teacher) approved by the order of the Ministry of labor and social protection of the Russian Federation from October 18, 2013.

In the context of those changes, the goal of the requirement of the Government of the RF to establish a succession pool in the general education system has a systemic nature. Let us explain that statement. The current situation in the labor market of Russia is quite complicated. Despite the lack of obvious unemployment problems, the market is characterized by human resources disbalance. Like in many Western states, in Russia a teaching profession is associated with relatively low social status and has low social appeal for people. However, no correlation between economic and social status of people working in that profession has been determined. According to the above-mentioned Decree of the Government of the RF, "advancing education of teachers must be accompanied with raising the average salary by 2013 up to the average salary in the corresponding region and preventing it from falling below that level." According to the economic indicators of 2015, that requirement was met, but it failed to solve the human resources issue in general. Students with pedagogical degrees tend not to choose educational sphere to start their career . The state invests funds to future educational human resources by allocating state-funded places in universities. However, as young specialists tend not to choose jobs in their degree fields, those investments result in losses. In the USSR, that problem was solved through compulsory allocation of jobs among graduate students. In today's democratic society, that method of providing an educational system with human resources is considered as a rather controversial practice. At present, one of the ways of addressing that issue is succession pool establishment.

\subsection{Importance of the Problem}

The issue of determining effective ways of succession pool establishment in the general education system of the RF requires special attention. It is obvious that application of traditional scenarios of generating a succession pool typical for private organizations may be inapplicable in state organizations. Due to their special nature, the established mechanisms of succession pool generation in military and law enforcement agencies in Russia also cannot be considered as a reference model for educational system as well.

Succession pool is defined as a specially selected group of employees of an organization for future vertical (and sometimes horizontal) turnover to generate and develop managerial staff of an organization. Application of practice of succession pool generation is aimed at fulfilling the following functions: personnel motivation; preservation of knowledge and experience; monitoring; cost saving (Armstrong, 2006; Bogatyireva \& Barmina, 2013; Tatarnikov, 2009; Kibanova, 2010; Shekshnya, 2003; Shinina, 2013).

Analysis of the relevant information published on official websites of the subjects of the RF showed that to establish a succession pool, federal and local executive authorities in educational sphere use a traditional definition of that concept: they select the most promising educational staff as potential candidates to fill in vacant, mostly managerial positions.

In the context of the above-mentioned issues, there is a need to develop mechanisms of succession pool generation taking into account special features of the general education system in the RF and regional educational systems of the subjects of the RF, which are components of the Russian educational system.

Therefore, the goal of this research is to analyze problems and prospects of succession pool establishment in the general education system of the RF. 


\subsection{Relevant Scholarship}

Despite the fact that the theory of human resources management has been elaborately studied by scholars, including the practice of succession pool establishment, there are few publications by Russian authors studying special features of applying that practice in the general education system. Such authors as Dmitriev (2012) and Chechel (2014), discuss the experience of local executive authorities in establishing a succession pool in the general education system. Using a narrow definition of the concept "succession pool", the authors associate it with practice of replacing vacant managerial positions in an educational institution. A spacious approach to the issue of forming a succession pool in the general education system is used in the works by Oparina $(2012,2013)$ and Potashnik (2012). The authors of this article share the ideas expressed by those researchers.

\subsection{State Hypotheses and Their Correspondence to Research Design}

A working hypothesis of this research consists in the assumption that succession pool establishment in the general education system is implemented by local executive bodies as a mere formality rather than in a consistent manner. The practice of succession pool generation focuses mainly on managerial positions, which proves a narrow and incomplete understanding of the practice of succession pool generation. The main reason is misunderstanding by heads of municipal executive authorities of the goals set at the federal level, and insufficient perception of importance of succession pool establishment in the general education system at every level and every stage of preparation and further education of a specialist.

\section{Method}

\subsection{The method of statistical survey}

The program of research included: operationalization of basic concepts, determination of basic variables-problems of human resources in general education defined in the beginning of theoretical analysis, analysis of documents and primary mathematical treatment of received data.

\subsection{Methods of analysis and measurement}

The basic method of empirical study was analysis of documents, during which the main concepts were determined: succession pool, job bank, educational staff, young specialists, turnover. During mathematical treatment, the received data in percent combined by federal regions was summed by several criteria: availability of a succession pool and development of a succession pool; main human resources problems in the general education system affecting the studied issue.

\subsection{Description of the Study Sample}

The sample comprised all subjects of the Russian Federation, regardless whether they published online documents about succession pool establishment in the general education system.

The process of succession pool generation in various regions is discussed in the following types of documents:

1) Decrees, orders, public reports (e.g., "About approving Regulation on competitive selection of heads of educational institutions in the Karachay-Cherkess Republic"; "About results of performance of Ministry of education of Sakha Republic (Yakutia) in 2013"; Report of Kamchatka Krai "About results of implementation of National educational initiative "Our New School" in 2011", etc.);

2) Programs for development and modernization of education (e.g., "Development of general education of Chechen Republic for 2014-2018"; "About approving Measures for modernization of general education aimed at implementation of the national educational initiative "Our New School" for 2011-2015 of the Government of Amur Oblast", etc.);

3) Program and methodical documents on succession pool development (e.g., "Consolidation and development of human resources potential in the educational system of Perm"; "Methodical guidance on establishment of succession pool for heads of institutions under the Department of education, science, and youth policy of Voronezh Oblast", etc.) 


\section{Results}

According to the Federal Law from February 9, 2009 "About providing access to information on performance of federal and local self-governing authorities", local executive authorities are to disclose information about their performance in the media, including the Internet. As succession pool establishment in the general education system is an essential part of that performance, lack of the relevant information can point out to either lack of that kind of activity, or non-compliance with the above-mentioned law. In any case, lack or availability of information about succession pool establishment in the general education system can serve as a subject of quantity and quality analysis.

Figure 1 shows quality analysis of information about succession pool establishment in the subjects of the RF combined by federal districts.

Figure 1. Application of the practice of succession pool establishment in the general education system in the federal districts of the RF

As Figure 1 shows, a succession pool is available in more than a half of the federal districts (average value is 57\%), with Volga Federal District (70\%) and Ural Federal District (67\%) leading the group. North Caucasian Federal District (37\%) and Southern Federal District (40\%) have the least established succession pools. Information about succession pool development is presented on more than a half of the official websites of the regions of the federal districts (average value is 46\%). Northwestern Federal District (80\%) and Ural Federal District are leaders in development of succession pools. Problems surrounding development of succession pools are registered in Siberian Federal District (25\%), Central Federal District (30\%), and North Caucasian Federal District (37\%). All established succession pools (the two indicators are equal) are actively developed in Southern Federal District, Ural Federal District, and North Caucasian Federal District. Northwestern Federal District demonstrates a rather peculiar situation: there is more information about development of succession pools (80\%) than officially established succession pools (62\%).

Synthesis of areas of succession pool development allows to identify special characteristics of using that practice in the general education system. Table 1 shows main programs for establishment and development of succession pool in the general education system of the federal districts.

Table 1. Programs for development of succession pools in the general education system of the federal districts of the RF.

\begin{tabular}{|c|c|}
\hline Federal district & Programs for development of succession pools \\
\hline Central (CFD) & $\begin{array}{l}\text { "School of succession managerial pool for local educational institutions"; "Management"; education in } \\
\text { the field of labor legislation, legislation base, providing electronic services }\end{array}$ \\
\hline Southern (SFD) & $\begin{array}{l}\text { Seminars for succession pool to replace heads of educational institutions, monitoring of succession } \\
\text { pool for heads of general and further education systems }\end{array}$ \\
\hline Northwestern (NWFD) & $\begin{array}{l}\text { "State-of-the-art practices to manage an organization"; "Organization management"; "Management in } \\
\text { education"; "Schools for young managers"; monitoring of professional development of succession pool } \\
\text { to replace heads of educational institutions; personnel renewal and turnover }\end{array}$ \\
\hline Far Eastern (FEFD) & $\begin{array}{l}\text { "School for succession pool candidates"; analysis of effectiveness of using succession managerial } \\
\text { pool to occupy managerial positions in educational institutions }\end{array}$ \\
\hline Siberian (SFD) & $\begin{array}{l}\text { "Management in education"; "Succession pool generation as a practice of human resources } \\
\text { management"; development of legal framework regarding introduction of competitive system to fill in } \\
\text { vacant positions of heads of state (local) general education institutions, turnover of managerial staff }\end{array}$ \\
\hline Ural (UFD) & $\begin{array}{l}\text { "Current educational management"; "State-of-the-art management practices for succession pools for } \\
\text { educational institutions»; "Organization management"; "Practices of human resources management"; } \\
\text { systemic work aimed at preparing the required managerial staff }\end{array}$ \\
\hline Volga (VFD) & $\begin{array}{l}\text { "Human resources management"; "Current educational management"; "Systemic managerial work, } \\
\text { improvement of management effectiveness, and personal managerial skills" }\end{array}$ \\
\hline North Caucasus (NCFD) & "Preparation of managerial human resources in health care and education in 2011-2014" \\
\hline
\end{tabular}

As one can see from Table 1, almost all programs for succession pool development focus on managerial staff in general education system. Job banks reaching outside managerial staff are established only in some regions of CFD (Voronezh Oblast, Ryazan Oblast, Tula Oblast) and NWFD (Arkhangelsk Oblast, Murmansk Oblast). Most programs for succession pool development do not take into account special characteristics of the general education system (e.g, North Caucasus Federal District has a program which fails to differentiate between management of educational institutions and health care organizations). Programs for development of succession managerial pools, which take into account special features of working in the secondary education system, are implemented in Central Federal District, Siberian Federal District, Ural 
Federal District, and Volga Federal District.

Real work aimed at succession pool establishment can be estimated by two criteria: firstly, by conducting competitions for filling in vacant positions and availability of bank of educational jobs, secondly, by results of succession pool development.

Figure 2 contains information about conducting competitions to fill in vacant positions with candidates from a succession pool and availability of bank of educational jobs in the federal districts.

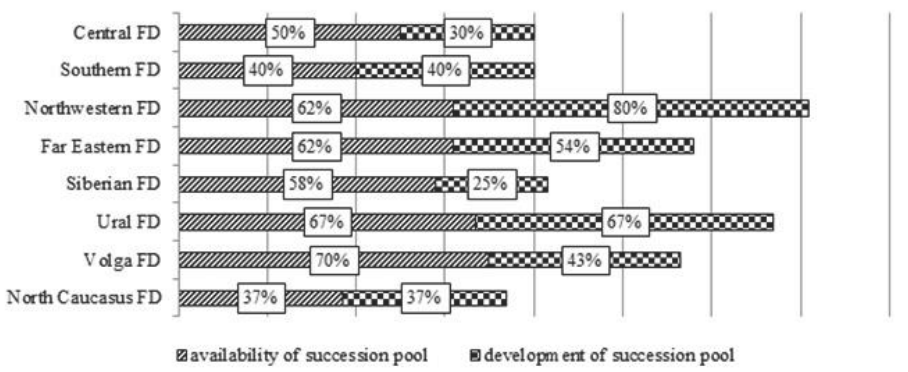

Figure 2. Information about conducting competitions to fill in vacancies from succession pools and availability of educational jobs bank in the federal districts of the RF

Online information about conducting competitions to fill in vacancies from succession pools is available in $16 \%$ of the regions of the federal districts, with Volga Federal District (31\%), Siberian Fedral District (25\%), North Western Federal District (20\%) and Southern Federal District (20\%) leading in that area of activity. In the regions of Central Federal District (0\%), North Western Federal District (8\%), and Far Eastern Federal Districts (8\%), information about conducting competitions to fill in vacancies from succession pools is either not published, or insufficient. Bank of educational jobs are established in Central Federal District (18\%) and North Western Federal District (16\%) only. It is worth noting that those two federal districts the practice of succession pool establishment is applied not only regarding managerial positions, but also educational personnel in general.

In addition, it should be noted that information about the results of succession pool development in the general education system is available for Far Eastern Federal District only.

Therefore, despite the information about succession pool development available on official websites of the regions of the federal districts, in practice it cannot help make a conclusion about real nature or effectiveness of that area of activity.

In addition, the Government of the RF drew special attention to the practice of succession pool establishment in the general education system due to lack of human resources in that sphere.

During the analysis of the above-mentioned documents, the following problems were identified: aging of educational staff, including both teachers and heads of educational institutions; lack of consistent and increasing inflow of young specialists in the education system; further education of succession pool. Figure 3 presents that information in more detail.

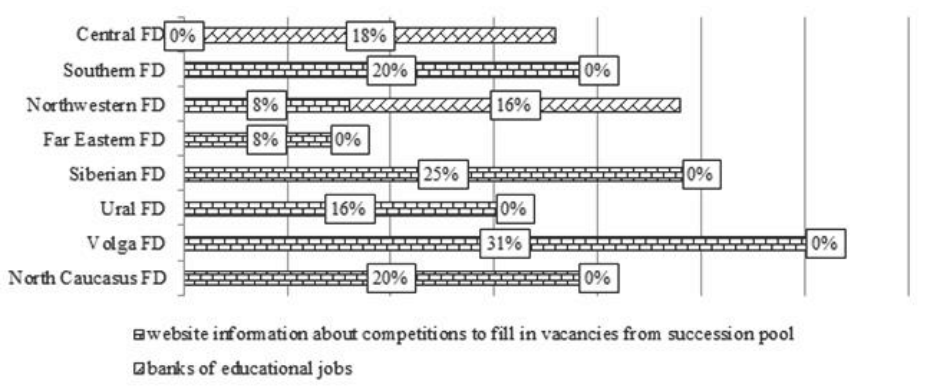

Figure 3. Human resources problems in general education system of the federal districts of the RF 
Aging of educational staff is characteristic of 22 regions ( $26 \%$ ); problems of attracting young specialists-22 regions (26 $\%)$; further education of succession pool- 24 regions ( $28 \%)$.

Lack (although a significantly slighter one) of educational staff is identified in such regions as Arkhangelsk Oblast, Leningrad Oblast (NWFD), Amur Oblast, Sakhalin Oblast, Chukotka Autonomous Okrug (FEFD), Chelyabinsk Oblast (UFD). Oblast).

Some regions lack precise mechanisms of regular turnover of managerial staff (Sakhalin Oblast, Leningrad

Comparing information about the practices used to establish a succession pool (Figure 1., Table 1.) with information about human resources problems in the general education system in the regions of the RF allows to reveal the following contradiction: a succession pool is established to fill in only vacant managerial positions in the general education system, while main problems of human resources relate not only to heads of educational institutions, but mainly to educational staff.

\section{Discussion}

It is obvious that while addressing the issue of establishment and development of succession pool in the general education system of the RF, the notion "succession pool" should not be applied to managerial staff only (heads, deputy heads). That notion must also relate to staff of educational institutions and their structural divisions. In particular, lack of human resources typical for the general education system of the RF is experienced at three levels at least. Firstly, this means physical lack of educational staff in a number of regions, which is explained by aging of human resources and insufficient inflow of young specialists. Secondly, there is a lack of educational staff which would meet the requirements set forth in the legislation, conform with current social expectations, and aim to modernize the system. This means professional aging ("depreciation") of educational staff. Unlike physical lack of educational personnel, this lack is practically impossible to identify on a large scale. The most rational tool to fill that shortage is competence of the head of an educational institution. Thirdly, the general education system experiences a lack of human resources that have an explicit innovation potential. This is especially relevant, taking into account the strategic task of innovative development set by the Government of the RF.

In the context discussed above, there is a need to expand the practice of succession pool establishment in the following areas: operating pool, strategic pool, and young specialists (Oparina, 2012). It is also worth noting that the Decree of the Government of the RF from December 8, 2011 "About the Strategy for innovative development of the RF till 2020" contains an expanded definition of a succession pool. In addition, the Decree prescribes to establish a succession pool in the general education system of the RF and to develop mechanisms of regular turnover of managerial staff.

Operating succession pool is a succession pool of human resources which is aimed at filling in concrete vacant positions. According to the research, in the practice of succession pool establishment in the general education system, operating succession pool is the most demanded practice of managing managerial staff of an educational institution.

Strategic succession pool is a succession pool of experienced educational staff, including employed and unemployed specialists, which can cover the lack of human resources in their region or other region (horizontal turnover). That succession pool does not focus on filling in concrete positions. Strategic succession pool must comprise of the following groups: firstly, highly-qualified specialists with pedagogical education that for some reasons are unemployed or work in a sphere other than educational sphere (recruiting) (Potashnik, 2012); secondly, educational staff of the general education system which are ready for horizontal turnover on a constant or temporary basis (e.g., work experience, sharing expertise) (this calls for the need to develop tools to stimulate professional mobility of educational staff); thirdly, top-ranked specialists employed in production sphere or other educational systems (headhunting) (Potashnik, 2012). Decree of the Government of the RF from December 8, 2011 "About the Strategy for innovative development of the RF till 2020 " focuses on the last category of potential succession pool candidates in the general education system: institutions of general education are advised to upgrade professional orientation of future teachers, which implies, among other things, involving in educational activity those people who do not have pedagogical education but can work with children and love it.

Establishment of a strategic succession pool implies constant activities (including distant working) aimed at preserving and developing professional skills of candidates. Development of strategic succession pool is associated with generation of regional and federal banks of jobs in the general education system. For a rather long time already, educational system management in the USA has been using teachers-on-reserve practice which is implemented through online market of educational jobs for candidates from succession pools (http://www.teachersonreserve.com).

The third area is a succession pool generated from young specialists, including students, master's degree 
students, and doctoral students. Implementation of that practice requires diverse activities aimed at attracting the abovementioned categories of specialists as participants of a succession pool in the general education system.

\section{Conclusion}

Effectiveness of the practice of succession pool establishment in the general education system depends mainly on transparency and effectiveness of tools applied for human resources development, which rules out superficial execution of the relevant instructions. At the same time, generation and development of a succession pool through focusing on potential of a strategic succession pool and a pool of young specialists can become an effective tool used for regulation of human resources in the general education system. In the USSR, balance of human resources was maintained through compulsory allocation of jobs among graduate students. The current understanding of a succession pool is based on free choice of professional career, which calls for the need to address such issues as raising social and economic status of educational staff and making professional mobility an essential part of life of qualified educational staff.

\section{Acknowledgements}

This research is a part of scientific and methodical work set in the state task of the Ministry of education and science of the Russian Federation in 2015.

\section{References}

Armstrong, M. (2006). Armstrong's handbook of human resource management practice. A handbook of human resource management practice (10th ed.).

Bogatyireva, O. N., \& Barmina, E. Y. (2013) Kadrovyie tehnologii v sisteme upravleniya personalom. Uchebnoye Posobie. SPb.

Chechel, I. D. (2014). Establishment of succession pool for educational institutions. Education Management: Theory and Practice, 1, 105-119.

Dmitriev, D. A. (2012). The main factors of innovative human resource development of heads of local education system. Vector Science TGU, 1(8), 135-138.

Fox, D. J. (2000). Teaching of Reserve: A non-native Perspective. Alberta: Lethbridge.

Levi, R. (2009). Innovative Approaches in Project Management for Personnel in the Educational and Public Administration Fields. HaifaJászberény.

Oparina, N. N. (2012). Training and development of succession pool. Scientific works of the Department of state administration, 8, 341353.

Oparina, N. N. (2013). Establishment of succession pool. Russian strategy, 8, 1-9.

Potashnik, M. M. (2012) . Human resources management in the educational system. Shkolnyie tehnologii, 4, 56-61.

Shekshnya, S. V. (2003). HR management in today's organization. M.: Biznes-shkola INTEL-SINTEZ.

Shinina, T. V. (2013). Sucession pool: Current state of the issue and ways of addressing it. Paper presented at Collection of scientific articles from I (IV) International scientific and practical conference, Moscow State Psychological and Pedagogical University. In M. G. Kovtunovich (Ed.), Socio-economic and psychological problems of management. M.: MGPPU. Retrieved from http://psyjournals.rul

Tatarnikov, A. A. (2009). Human resources management in corporations of the USA, Japan and Germany. M.: Progress.

Kibanova, A. Y. (Ed.). (2010). Human resources management in organization. M.: INFRA-M. 